\title{
Transmissibility of Field Isolates of Soybean Viruses by Aphis glycines
}

\author{
A. J. Clark and K. L. Perry, Department of Botany and Plant Pathology, Purdue University, West Lafayette, IN \\ 47906 and Department of Plant Pathology, Cornell University, Ithaca, NY 14853
}

\begin{abstract}
Clark, A. J., and Perry, K. L. 2002. Transmissibility of field isolates of soybean viruses by Aphis glycines. Plant Dis. 86:1219-1222.

During the 2001 growing season, 191 symptomatic soybean (Glycine max (L.) Merr.) plants were dug from production plots in Indiana, Wisconsin, and Kentucky. Alfalfa mosaic virus (AMV), Bean pod mottle virus (BPMV), Bean yellow mosaic virus (BYMV), Peanut stunt virus (PSV), Tobacco ringspot virus (TRSV), and Soybean mosaic virus (SMV) were identified. No mixed infections were observed. The ability of the soybean aphid (Aphis glycines Matsamura) to transmit field isolates of these viruses was tested. Using naturally infected field- or greenhouse-grown soybean plants as sources, six isolates of SMV and two isolates of AMV were transmitted using a short feeding assay. One of two isolates of TRSV was transmitted by A. glycines in one of four experiments using an extended feeding transmission assay. BPMV was not transmitted by A. glycines in assays involving 11 field isolates and over 840 aphids. One field isolate each of BYMV and PSV were tested and no transmission by A. glycines was observed.
\end{abstract}

Until the year 2000, U.S. soybean was thought to be free of colonizing aphids. Aphid transmission of viruses in the field was limited and due to noncolonizing aphids (1,11). In August 2000, the Asian soybean aphid, Aphis glycines, was identified from specimens collected in southern Wisconsin and northern Illinois. By the end of the 2001 growing season, A. glycines had been recorded from Virginia to eastern North Dakota and from Manitoba to Missouri. This maximal distribution is most likely considerably larger than the actual area of establishment, which is limited to areas where A. glycines successfully overwinters as eggs on Rhamnus spp. (D. Voegtlin, personal communication). The introduction and spread of A. glycines within North America could affect the transmission of viruses into and within soybean plants. A. glycines has been demonstrated to transmit a single isolate each of Soybean mosaic virus (SMV) and $A l$ falfa mosaic virus (AMV) (10). The objective of this study was to test multiple field isolates of these and other soybean viruses for transmission by A. glycines. Aphid transmissibility can be lost from laboratory strains that have been repeatedly passaged by mechanical inoculation $(2,12,17,25)$. To avoid this possibility, naturally infected

Corresponding author: K. L. Perry

E-mail: KLP3@cornell.edu

This work was supported by USDA/CSREES grant \#2001-03139 and funds from the Purdue School of Agriculture.

Accepted for publication 5 June 2002.

Publication no. D-2002-0826-02R

(C) 2002 The American Phytopathological Society field-grown plants, in addition to greenhouse-raised infected plants, were used as sources for aphid acquisition.

\section{MATERIALS AND METHODS}

Field sampling and virus isolates. Between July and September 2001, soybean plants showing virus-like symptoms were dug from 57 production plots in Indiana, 2 in Wisconsin, and 2 in Kentucky. A total of 18 composite samples of 10 leaflets from asymptomatic soybean plants also were collected, with each leaflet from a different plant. Plants were placed in plastic bags, watered, transported on ice, and stored at $4^{\circ} \mathrm{C}$ prior to virus testing and transmission studies. Soybean cv. Williams 82 was used for mechanical and aphid transmission throughout this study. The seed were from a single lot grown in Indiana. The presence of seedborne SMV was evaluated by seedling grow-out experiments of approximately 6,000 seed in which no symptoms were observed. Additionally, throughout this study, seedlings were employed during serological testing as negative controls; none gave a positive reaction for SMV. Symptomatic field-grown plants were identified as containing virus by serological methods. To confirm the presence of virus, leaf tissue was ground in $10 \mathrm{mM}$ sodium phosphate buffer ( $\mathrm{pH}$ 7.0) and mechanically inoculated onto soybean cv Williams 82. Nicotinana clevelandii and $N$. tabacum were used as additional hosts species for Peanut stunt virus (PSV) and AMV. Phaseolus vulgaris cv. Bountiful was used as an indicator species for Bean yellow mosaic virus (BYMV) and P. vulgaris. cv. Pinto for Bean pod mottle virus (BPMV).

Serological testing. An antigen-coated plate enzyme-linked immunosorbent assay
(ACP-ELISA; 18) was used to test field samples and greenhouse-grown plants for AMV, BPMV, BYMV, Cucumber mosaic virus (CMV), PSV, SMV, Tobacco ringspot virus (TRSV), and Tobacco streak virus (TSV). For the field samples and greenhouse-grown target plants from transmission assays, absorbance values threefold higher than the uninfected greenhouse-grown soybean controls were considered positive. The laboratory isolates used as positive controls for AMV, BPMV, SMV, TRSV, and TSV were from the collection of Richard Lister. Other positive controls used were BYMV B94-5 from Said Ghabrial, CMV-Fny (27), and PSV-J (14). BPMV, BYMV, and SMV antisera were the kind gift of Said Ghabrial. AMV antiserum was provided by John Randles. TRSV and TSV antisera were from the collection of Richard Lister. Polyclonal rabbit antibodies against glutaraldehydefixed virions of CMV-Fny and PSV-J were prepared as described by Francki and colleagues $(5,6)$.

Aphid transmission. A. glycines aphids were raised in growth chambers on soybean V97-9003. This soybean line was provided by G. Buss and is an isoline of 'Essex' containing the Rsv4 gene conferring resistance to SMV (15). This SMVresistant germ plasm was employed to reduce the possibility of introduction of seedborne virus. Apterous A. glycines aphids were harvested and starved at room temperature for 1 to $4 \mathrm{~h}$ prior to use. Myzus persicae aphids were raised in a growth chamber on Chinese cabbage (Brassica rapa $\mathrm{L}$.) and starved for either 1 to $2 \mathrm{~h}$ at room temperature or at $4^{\circ} \mathrm{C}$ overnight. Stem sections with a single symptomatic trifoliate leaf were cut and placed in a water-filled plastic tube that was then sealed with parafilm. Aphids were transferred onto leaflets for virus acquisition. To recover viruses that were nonpersistently transmitted, a short feeding assay was used. Aphids were observed for probing behavior and allowed to probe for 0.5 to $3.0 \mathrm{~min}$ before being transferred to a target plant. Ten individuals were placed on each target plant, held overnight, sprayed with acephate (Orthene, Valent USA Corporation, Walnut Creek, CA) per the recommended rate, and transferred to the greenhouse. An extended feeding assay was used to recover viruses that were persistently transmitted; the same source material that had been used for the short feeding assay was employed. Aphids were allowed to feed on the source material for 2 to 3 days 
at room temperature. Then, 20 to 40 aphids were transferred to each target plant and allowed to feed for 2 to 3 days. The target plants then were treated with acephate and transferred to the greenhouse. For each set of transmissions, at least one SMV isolate transmissible by $A$. glycines was included as a positive control. Target plants were tested for the presence of the relevant virus by ACP-ELISA 3 to 5 weeks post inoculation.

\section{RESULTS AND DISCUSSION}

In all, 191 symptomatic plants were collected from the 61 plots: 175 plants from sites in Indiana, 10 from Wisconsin, and 6 from Kentucky. Of these, 132 tested positive for SMV, AMV, TRSV, PSV, BYMV, or BPMV. Using greenhouse-grown positive controls, absorbance values were 17to 130 -fold higher than the negative controls. The absorbance values for negative controls after $1 \mathrm{~h}$ were between 0.001 and 0.060 . The sensitivity of the assay was sufficient to detect antigen in the positive control infected-plant extracts when diluted 20-fold or more.

Eleven isolates tested positive for SMV, and the presence of virus was confirmed for these and other viruses by the production of systemic symptoms following mechanical inoculation of soybean cv. Williams 82, except where mentioned. Five SMV field isolates were tested for trans- mission by the short feeding assay and all were transmitted by A. glycines (Table 1). Transmission of SMV from field material was observed for isolates N15, N36, N37, and KY3, demonstrating that SMV from naturally infected field-grown soybean is transmissible by A. glycines. Transmission of SA2 by A. glycines was observed from greenhouse-grown and inoculated plants but not from the original field material itself. This result demonstrates the importance of making a distinction in the assays between field-grown and greenhousereared material (Table 1). All SMV field isolates were transmitted in the extended feeding assay when this was performed using greenhouse-grown infected soybean as source plants. In contrast, when field material was tested using this extended feeding assay, no transmission of SMV occurred. In this and other cases, the lack of transmission from the field-grown material was probably due to the condition of the source leaves in conjunction with desiccation that occurred over the 2- to 3-day acquisition period. The aphid transmission of SMV observed in the extended feeding assay is presumably by a nonpersistent mechanism, because the virus also is able to be transmitted following short acquisition periods.

Two AMV isolates were detected serologically and the presence of virus confirmed because systemic symptoms were produced following mechanical inoculation of $N$. clevelandii as well as soybean cv. Williams 82. In the field, the original source plants exhibited distinctive bright yellow mosaic symptoms. Isolate SE12 was transmitted by A. glycines using fieldand greenhouse-grown sources, whereas KY1 was transmitted only from greenhouse-grown material (Table 1). An AMV isolate obtained from alfalfa, ARC6/8, was transmitted from alfalfa to soybean by $A$. glycines using the short feeding assay. In two separate experiments using 10 aphids per plant, AMV ARC6/8 was transmitted to two of six target soybean plants. AMV commonly is found in alfalfa and this host represents a potential source of inoculum for the movement of AMV into soybean. These data demonstrate transmission of both SMV and AMV from infected fieldgrown material and extend the number of U.S. isolates tested for transmission by $A$. glycines.

Two isolates of TRSV were recovered from infected soybean, T8-4 and 61C. In only one instance was transmission of TRSV by A. glycines observed (Table 1). In this case, greenhouse-grown T8-4-infected plants were used as sources for an extended feeding assay and 1 out of 12 target plants became infected. Transmission by A. glycines of T8-4 from the fieldgrown material was not observed. Transmission of T8-4 by A. glycines using the

Table 1. Transmission of field and laboratory virus isolates by Aphis glycines

\begin{tabular}{|c|c|c|c|c|c|c|}
\hline \multirow[b]{3}{*}{ Virus $^{b}$} & \multirow[b]{3}{*}{ Strain } & \multicolumn{4}{|c|}{ Transmission $^{\mathrm{a}}$} & \multirow[b]{3}{*}{ Source $^{c}$} \\
\hline & & \multicolumn{2}{|c|}{ Short feeding } & \multicolumn{2}{|c|}{ Extended feeding } & \\
\hline & & Field & Greenhouse & Field & Greenhouse & \\
\hline \multirow[t]{6}{*}{ SMV } & MW & & $10 / 12$ & & $0 / 3$ & Seedborne from Midwest \\
\hline & N15 & $3 / 3$ & $5 / 6$ & $0 / 3$ & $6 / 6$ & Whitley County, IN \\
\hline & N36 & $2 / 3$ & $4 / 6$ & $0 / 3$ & $6 / 6$ & Tippecanoe County, IN \\
\hline & N37 & $2 / 3$ & $6 / 6$ & $0 / 3$ & $6 / 6$ & Tippecanoe County, IN \\
\hline & KY3 & $3 / 3$ & $6 / 6$ & $\ldots$ & $6 / 6$ & Fayette County, KY \\
\hline & SA2 & $0 / 3$ & $8 / 9$ & $\ldots$ & $8 / 9$ & Tippecanoe County, IN \\
\hline \multirow[t]{3}{*}{ BYMV } & SA6 & $0 / 3$ & $0 / 9$ & $0 / 3$ & $0 / 9$ & Tippecanoe County, IN \\
\hline & Scott & $\ldots$ & $0 / 9$ & $\ldots$ & $0 / 9$ & Simon Scott \\
\hline & B94-5 & $\ldots$ & $0 / 9$ & $\ldots$ & $0 / 9$ & Said Ghabrial \\
\hline \multirow[t]{2}{*}{ AMV } & SE12 & $3 / 3$ & $3 / 6$ & $0 / 3$ & $2 / 6$ & Jennings County, IN \\
\hline & KY1 & $0 / 3$ & $1 / 6$ & $0 / 3$ & $2 / 6$ & Fayette County, KY \\
\hline PSV & PP24 & $0 / 3$ & $\ldots$ & $0 / 3$ & $\ldots$ & White County, IN \\
\hline \multirow[t]{2}{*}{ TRSV } & $61 \mathrm{C}$ & $0 / 3$ & $0 / 6$ & $0 / 3$ & $0 / 9$ & Tippecanoe County, IN \\
\hline & T8-4 & $0 / 3$ & $0 / 12$ & $0 / 3$ & $1 / 9$ & Tippecanoe County, IN \\
\hline TSV & SV14 & $0 / 9$ & $\ldots$ & $\ldots$ & $0 / 9$ & Richard Lister \\
\hline \multirow[t]{11}{*}{ BPMV } & $8-2$ & $0 / 3$ & $\ldots$ & $\ldots$ & $\ldots$ & Tippecanoe County, IN \\
\hline & CDTC-2 & $0 / 3$ & $\ldots$ & $\ldots$ & $\ldots$ & Tippecanoe County, IN \\
\hline & PP14 & $0 / 3$ & $\ldots$ & $0 / 3$ & $\ldots$ & Porter County, IN \\
\hline & PP22 & $0 / 3$ & $\ldots$ & $0 / 3$ & $\ldots$ & Porter County, IN \\
\hline & V10 & $0 / 3$ & $\ldots$ & $0 / 3$ & $\ldots$ & Knox County, IN \\
\hline & V27 & $0 / 3$ & $\ldots$ & $0 / 3$ & $\ldots$ & Knox County, IN \\
\hline & V40 & $0 / 3$ & $\begin{array}{l}\cdots \\
\cdots\end{array}$ & $0 / 3$ & $\cdots$ & Knox County, IN \\
\hline & W6 & $0 / 3$ & $\ldots$ & $0 / 3$ & $\ldots$ & Clinton County, IN \\
\hline & W12 & $0 / 3$ & $\ldots$ & $0 / 3$ & $\ldots$ & Clinton County, IN \\
\hline & $61 \mathrm{~A}$ & $0 / 3$ & $\ldots$ & $0 / 3$ & $\ldots$ & Tippecanoe County, IN \\
\hline & N17 & $\ldots$ & $\ldots$ & $0 / 3$ & $\ldots$ & Whitley County, IN \\
\hline Unidentified & $\mathrm{N} 20$ & $0 / 3$ & $0 / 6$ & $2 / 3$ & $0 / 3$ & Whitley County, IN \\
\hline
\end{tabular}

${ }^{a}$ Data expressed as the number of infected soybean plants over the total number of plants. Target plants were rated for infection by visual symptoms and enzyme-linked immunosorbent assay except for N20, which was scored on the basis of symptoms alone.

${ }^{\mathrm{b}} \mathrm{SMV}=$ Soybean mosaic virus, $\mathrm{BYMV}=$ Bean yellow mosaic virus, $\mathrm{AMV}=$ Alfalfa mosaic virus, $\mathrm{PSV}=$ Peanut stunt virus, $\mathrm{TRSV}=$ Tobacco ringspot virus, $\mathrm{TSV}=$ Tobacco streak virus, and BPMV = Bean pod mottle virus.

${ }^{c}$ All isolates are from this study except where the name of the individual who provided the virus is noted. 
short feeding assay was not observed, nor was any transmission of isolate $61 \mathrm{C}$ in either assay. The transmission of T8-4 in the extended feeding assay but not the short feeding assay might simply reflect the greater number of aphids employed in these experiments ( 240 to 480 versus 150 ) rather than being due to the necessity of an extended acquisition period per se. TRSV has been shown to be nematode transmitted to soybean roots, although an aerial vector also was suspected (3). TRSV also has been reported to be aphid transmissible $(19,22)$, and is seed transmitted in soybean (23).

A single PSV isolate, PP24, was detected by ACP-ELISA and recovered by mechanical inoculation onto $N$. clevelandii and $N$. tabacum. Despite numerous attempts, PP24 could not be mechanically transferred into G. $\max$ cv. Williams 82 . Transmission of this PSV isolate by $A$. glycines from the original field plant to soybean also was not observed (Table 1). PP24 was easily transmitted mechanically from Nicotiana sp. to Nicotiana sp.; therefore, the lack of mechanical transmission to soybean was unexpected. Resistance to PSV in G. max cultivars has not been studied well, and it may be that the Williams 82 has resistance that was not present in the original field plant. PP24-infected greenhouse-grown soybean plants were not available to use as source plants to repeat the soybean-to-soybean transmission work; therefore, transmission was tested from $N$. clevelandii to $N$. clevelandii using the short feeding assay. Using $10 \mathrm{~A}$. glycines aphids per plant, none of 14 target plants were infected; using $10 \mathrm{M}$. persicae aphids per target plant, the same result was obtained $(0 / 14)$. In contrast, when CMV-Fny infected $N$. clevelandii was used as a positive control, six of six target plants were infected using A. glycines and four of five infections were observed using $M$. persicae. A lack of transmission by either $A$. glycines or $M$. persicae was inconsistent with previous work, because PSV has been shown to be transmissible by $M$. persicae (9). This isolate recently may have lost its aphid transmissibility or may be transmissible only by other species of aphids; alternatively, its presence in the field plant may have been due to a seedborne infection.

Two isolates of BYMV were detected serologically, of which SA6 was recovered by mechanical inoculation onto soybean cv. Williams 82 and P. vulgaris cv. Bountiful. Sample NE23 was in poor condition and no virus was recovered by mechanical inoculation or aphid transmission. SA6 was not transmitted from naturally infected field-grown soybean tissue by A. glycines using either the short or extended feeding assays (Table 1). When greenhouse-grown SA6-infected soybean plants were used as source plants, this virus also was not transmitted by A. glycines in either transmission assay. Attempts to transmit SA6 using $M$. persicae with the short feeding assay also were unsuccessful (Table 2). Different isolates of BYMV have been described as transmissible (24) or nontransmissible (16) by $M$. persicae. BYMV also has been observed to lose aphid transmissibility after a single mechanical inoculation (25). This could possibly be a factor in the nontransmissibility of SA6 by $M$. persicae because only mechanically inoculated source plants were employed in testing for transmission by this aphid.

The single viable BYMV field isolate obtained in this study was not transmitted by $M$. persicae or A. glycines; therefore, additional laboratory isolates were tested. BYMV-Scott was transmitted by $M$. persicae using the short feeding assay (Table 2), but was not transmitted by A. glycines in either assay (Table 1). The clone of $A$. glycines used in this study was therefore unable to transmit an isolate transmissible by $M$. persicae. The isolate B94-5 was not transmitted by A. glycines or $M$. persicae in either of the assays (Tables 1 and 2).

BPMV was the most commonly detected virus in this study, with 114 of the field plants containing BPMV. BPMV isolates inoculated onto $P$. vulgaris cv. Pinto gave necrotic local lesions typical for this virus $(7,21)$. In all, 840 to 1,380 aphids were used to test for transmission by $A$. glycines in experiments involving 11 source plants and 57 target plants (Table 1). Three hundred aphids and 30 target plants were used in the short feeding assays alone. In no case was any transmission of a BPMV isolate observed. BPMV is known to accumulate to high levels in soybean (21) and to be efficiently beetle transmitted (26). The basis for the specificity in transmission by beetles but not aphids remains unknown. This study is unusual in that viruses such as BPMV sometimes are described as not being vectored by aphids, but transmission has rarely been rigorously assessed. Given the recent introduction and abundance of A. glycines, such an assessment is important.

Of the 191 samples, 59, or $31 \%$, did not test positive for any of the viruses. Many of the plants that proved negative had mild mottling symptoms that were likely due to abiotic factors. Material from four fieldgrown soybean plants exhibiting virus-like symptoms but not testing positive for virus by ELISA were used as source plants for A. glycines in both the short and extended feeding assays. An apparent transmission was observed only in one case, with the sample N20 ("Unidentified" in Table 1). The single mottled soybean plant N20 contained a putative disease-causing agent that was transmitted from field-grown tissue in the extended feeding assay and by the initial mechanical inoculation. In both cases, a distinct mottle mosaic was observed on the first 2 to 5 leaves of new growth (noninoculated tissue), but leaves from additional growth were asympto- matic. In subsequent trials, an infectious agent could not be transmitted by either aphid or mechanical inoculation, as determined by the appearance of symptoms. Thus, the presence of an unidentified transmissible agent was suggested but could not be confirmed.

TSV was not observed in any of the tested field plants. This was the only one of the seven viruses tested for that was not found in this study. Field material was not available; therefore, the laboratory strain SV14 was tested for transmission by $A$. glycines. TSV was not transmitted in either the short or extended feeding assay (Table 1). TSV is known to be thrip transmitted (13), but we are unaware of any reports of TSV transmission by aphids.

Only six isolates of SMV were found in Indiana, five of which were found in Tippecanoe County. In neighboring Kentucky, a survey of soybean viruses in 1975 and 1976 identified 12 isolates of SMV compared with 10 for BPMV (7). In comparison, there were proportionally more BPMV- than SMV-infected plants in the material collected in Indiana in 2001, a result consistent with the recently observed increase in the amount of BPMV in the North Central states (8). Eighteen composite negative controls, each consisting of 10 asymptomatic field-grown leaves, were collected during the course of this study. Of these, a single composite gave a positive reaction for SMV; the remaining controls were negative for all seven viruses for which field samples were tested. Like the majority of SMV isolates, this was from Tippecanoe County. These data suggest that asymptomatic SMV was present in the field that was not represented in the collected material.

A. glycines was observed throughout Indiana and often was abundant. All the SMV isolates tested in this study were transmissible by A. glycines; therefore, there is the potential for spread of this virus by A. glycines. AMV and TRSV also are present in soybean in Indiana. Based on the observed transmission of AMV from field-grown material in this study, it is likely that the incidence of AMV in soy-

Table 2. Nonpersistent transmission of virus by Myzus persicae ${ }^{\mathrm{a}}$

\begin{tabular}{llc}
\hline Virus $^{\mathbf{b}}$ & Strain & Transmission \\
\hline SMV & MW & $5 / 9$ \\
BYMV & Scott & $5 / 9$ \\
& B94-5 & $0 / 9$ \\
& SA6 & $0 / 9$ \\
AMV & SE12 & $0 / 9$ \\
\hline
\end{tabular}

a Data expressed as the number of infected soybean plants over the total number of plants. Target plants were rated for infection by visual symptoms and enzyme-linked immunosorbent assay.

b $\mathrm{SMV}=$ Soybean mosaic virus, BYMV = Bean yellow mosaic virus, and AMV = Alfalfa mosaic virus. 
bean will increase with the presence of the aphid. Alfalfa is a commonly grown perennial crop that can function as a reservoir for AMV and other viruses.

Mixed infections of SMV and BPMV have been shown to occur in the field (7). Surprisingly, no mixed infections were seen in the 191 soybean plants tested in this study. This was probably due to the low incidence of recovery of SMV in Indiana, where $92 \%$ of our plants were collected. If the number of SMV-infected soybean plants were to increase, mixed infections of SMV and BPMV would be more likely to occur. In that case, additional crop losses might be expected because a synergistic interaction occurs between these two viruses. This synergism results in elevated levels of BPMV and an associated increase in symptom severity (4). SMV alone has been shown to reduce yields of soybean $(11,20)$ and, even without the potential for synergistic interactions with other viruses, increased transmission of this virus in the field would be damaging.

\section{ACKNOWLEDGMENTS}

We thank S. Ghabrial, J. Randles, and J. Hill for providing antisera; S. Scott, L. Domier, and S. Ghabrial for virus isolates; T. Pfeiffer, G. Buss, and S. Abney for the kind gift of soybean seed; T. Phillips, S. Doun, T. Richards, R. Smith, H. Wiley, A. LeRoy, and G. Bossaer for their valuable assistance; and S. Gray for review of the manuscript.

\section{LITERATURE CITED}

1. Abney, T. S., Sillings, J. O., Richards, T. L., and Broersma, D. B. 1976. Aphids and other insects as vectors of soybean mosaic virus. J. Econ. Entomol. 69:254-256.

2. Badami, R. S. 1958. Changes in the transmissibility by aphids of a strain of cucumber mosaic virus. Ann. Appl. Biol. 46:554-562.

3. Bergeson, G. B., Athow, K. L., Laviolette, F.
A., and Thomasine, M. 1964. Transmission, movement and vector relationships of tobacco ringspot virus in soybean. Phytopathology 54:723-728.

4. Calvert, L. A., and Ghabrial, S. A. 1983. Enhancement by soybean mosaic virus of bean pod mottle virus titer in doubly infected soybean Glycine max cultivar York. Phytopathology 73:992-997.

5. Francki, R. I. B., and Habili, N. 1972. Stabilization of capsid structure and enhancement of immunogenicity of cucumber mosaic virus $(\mathrm{Q}$ strain) by formaldehyde. Virology 48:309315.

6. Francki, R. I. B. F., and Hatta, T. 1980. Cucumber mosaic virus: variation and problems of identification. Acta Hortic. 110:167-174.

7. Ghabrial, S. A., Pickard, C. M., and Stuckey, R. E. 1977. Identification and distribution of virus diseases of soybean in Kentucky. Plant Dis. Rep. 61:690-694.

8. Gu, H., Clark, A. J., de Sa, P. B., Pfeiffer, T. W., Tolin, S., and Ghabrial, S. A. 2002. Diversity among isolates of Bean pod mottle virus. Phytopathology 92:446-452.

9. Hebert, T. T. 1967. Epidemiology of the peanut stunt virus in North Carolina. (Abstr.) Phytopathology 57:461.

10. Hill, J. H., Alleman, R., Hogg, D. B., and Grau, C. R. 2001. First report of transmission of soybean mosaic virus and alfalfa mosaic virus by Aphis glycines in the new world. Plant Dis. 85:561.

11. Hill, J. H., Lucas, B. S., Benner, H. I., Tachibana, H., Hammond, R. B., and Pedigo, L. P. 1980. Factors associated with the epidemiology of soybean mosaic virus in Iowa. Phytopathology 70:536-540.

12. Jensen, D. D. 1959. Insects, both hosts and vectors of plant viruses. Pan-Pac. Entomol. 35:65-82.

13. Kaiser, W. J., Wyatt, S. D., and Pesho, G. R. 1982. Natural hosts and vectors of tobacco streak virus in eastern Washington. Phytopathology 72:1508-1512.

14. Karasawa, A., Nakaho, K., Kakutani, T., Minobe, Y., and Ehara, Y. 1991. Nucleotide sequence of RNA 3 of Peanut Stunt Virus. Virology 185:464-467.
15. Ma, G., Chen, P., Buss, G. R., and Tolin, S. A 1995. Genetic-characteristics of 2 genes for resistance to soybean mosaic virus in P1486355 soybean. Theor. Appl. Genet. 91:907-914.

16. Manglitz, G. R., and Kreitlow, K. W. 1960. Vectors of bean yellow mosaic viruses in ladino white clover. J. Econ. Entomol. 53:113115 .

17. Mossop, D. W., and Francki, R. I. B. 1977. Association of RNA 3 with aphid transmission of cucumber mosaic virus. Virology 81:177-181.

18. Mowat, W. P., and Dawson, S. 1987. Detection and identification of plant viruses by ELISA using crude sap extracts and unfractionated antisera. J. Virol. Methods 15:233247.

19. Rani, S., Verma, H. N., and Verma, G. S 1969. A virus disease of Petunia hybrida. Plant Dis. Rep. 53:903-907.

20. Ross, J. P. 1977. Effect of aphid transmitted soybean mosaic virus on yields of closely related resistant and susceptible soybean lines. Crop Sci. 17:869-872.

21. Semancik, J. S. 1972. Bean pod mottle virus. C.M.I./A.A.B. Descriptions of Plant Viruses no. 108.

22. Smith, F. F., and Brierley, P. 1955. Aphid transmission of tobacco ringspot virus in gladiolus. Plant Dis. Rep. 39:35.

23. Stace-Smith, R. 1985. Tobacco ringspot virus. C.M.I./A.A.B. Descriptions of Plant Viruses no. 309.

24. Swenson, K. G. 1954. Aphid transmission of a bean yellow mosaic virus. J. Econ. Entomol. 47:1121-1123.

25. Swenson, K. G., Sohi, S. S., and Welton, R. E. 1964. Loss of transmissibility by aphids of bean yellow mosaic virus. Ann. Entomol. Soc. Am. 57:378-382.

26. Walters, H. J. 1964. Transmission of bean pod mottle virus by bean leaf beetles. Phytopathology 54:240.

27. Zitter, T. A., and Gonsalves, D. 1991. Differentiation of pseudorecombinants of two cucumber mosaic virus strains by biologica properties and aphid transmission. Phytopathology 81:139-1443. 